\title{
Article
}

Mycosphere

\section{A new Phanerochaete (Polyporales, Basidiomycota) with brown subicular hyphae from Thailand}

\author{
Sádlíková $\mathbf{M}^{1}$ and Kout $\mathbf{J}^{2 *}$
}

\author{
${ }^{1}$ Department of Forest Protection and Entomology, Faculty of Forestry and Wood Sciences, Czech University of Life \\ Sciences Prague, Kamýcká 129, Praha 6 - Suchdol, CZ-165 00, Czech Republic; sadlikovam@fld.czu.cz. \\ ${ }^{2}$ Department of Biology, Geosciences and Environmental Education, Faculty of Education, University of Bohemia, \\ Klatovská 51, Plzen̆, CZ-306 19, Czech Republic; martial@seznam.cz
}

Sádlíková M, Kout J 2017 - A new Phanerochaete (Polyporales, Basidiomycota) with brown subicular hyphae in from Thailand. Mycosphere 8(8), 1124-1030, Doi 10.5943/mycosphere/8/6/4

\begin{abstract}
A new species of Phanerochaete, $P$. thailandica, is described from Thailand, it has resupinate fruiting body with smooth, beige, creamy hymenophore, a monomitic hyphal system, the presence of leptocystidia, ellipsoid spores and remarkable subicular layer composed of brown clamped hyphae with quasi-binding hyphae. Molecular analysis of rDNA ITS regions shows $P$. thailandica as an independent species. Phylogenetic analysis demonstrates the relationships with closely related species and confirms position the new species in the genus Phanerochaete.
\end{abstract}

Key words - Corticioid fungi - Phanerochaetaceae - Southeast Asia - Taxonomy

\section{Introduction}

Phanerochaete P. Karst. is widely spreading corticioid genus of fungi from Polyporales (Basidiomycota) and it was described by Finnish mycologist P.A. Karsten in 1889 (Karsten 1889). The species of Phanerochaete are characterized by the membranaceous, resupinate basidiocarps, a monomitic hyphal system, simple-septate generative hyphae (single or multiple clamps may be present in subiculum), clavate basidia and smooth, thin-walled, inamyloid, hyaline, cylindrical to ellipsoid basidiospores, and by causing white rot on both conifers and hardwoods (Eriksson et al. 1978, Burdsall 1985, Bernicchia \& Gorjón 2010, Wu et al. 2010). Morphologically, the genus Phanerochaete was divided to several sections and subgenera (Parmasto 1968, Burdsall 1985). Unsurprisingly, phylogenetic studies suggested that Phanerochaete is polyphyletic (de Koker et al. 2003, Wu et al. 2010, Floudas \& Hibbett 2015).

The genus Phanerochaete has been studied outside Europe more by H.H. Burdsall (1985) in North America and then in Asia by Sheng-Hua Wu (e.g. Wu 1990). Our attention is just aimed at tropical Asia where was collected specimen unknown species of Phanerochaete in Thailand. Our specimen was remarkable by brown hyphae in subiculum. Most species of Phanerochaete have hyaline hyphae, distinctly brown subicular hyphae are present only in several species that appear close to each other in phylogeny (Liu and He 2016). These species are known from America, Asia and New Zealand. The most of them are spreading in limited region of Asia from tropical southeast (mainly at Taiwan) up to central to western part of China (Wu 1995, Dai 2011, Liu and He 2016). Two more comprehensive monographs on Aphyllophoroid from mainland Asia (Himalaya and India) 
did not reveal any Phanerochaete species with brown subicular hyphae (Sharma 2012, Hakimi et al. 2013).

We were not able to assign our specimen to some known species of Phanerochaete (Burdsall 1985, Wu 1990, 1995, 1998, Bernicchia \& Gorjón 2010) and so we describe it as a new species here.

\section{Materials \& Methods}

The studied specimen was collected from Thailand on Koh Lanta Yai Island in 2015. The specimen is deposited in National Museum of Czech Republic (PRM, for herbarium acronym see Thiers 2017), isotype in mycological herbarium of the second author at Department of Biology, Geosciences and Environmental Education, University of West Bohemia (CBG).

Description on macroscopic characters is based on the observations in the field and dry specimen.

Microscopic characters were observed from dried herbarium specimen by using light microscope OLYMPUS BX51 in Melzer's solution and Congo Red in ammonia. Microscopic measurements are based on $100 \times$ oil immersion lens. Camera OLYMPUS DP72 was used to photograph some microscopic structure. The following abbreviations are used in descriptions below: $\mathrm{L}$ - mean spore length, $\mathrm{W}$ - mean spore width, $\mathrm{Q}-\mathrm{L} / \mathrm{W}$ ratio, $\mathrm{n}$ - number of measured spores.

Processing of DNA according to Spirin et al. (2015). DNA was isolated from herbarium specimen used the $\mathrm{CTAB} / \mathrm{NaCl}$ extraction buffer following procedure in Murray \& Thompson (1980). Nuclear rDNA (ITS regions) was amplified by using primer pair ITS4 and ITS5 (White et al. 1990). Data matrix contains 10 sequences, 9 from Genbank (Table 1) and one newly generated (deposited in GenBank). There were a total of 718 positions in the final dataset. Phlebiopsis flavidoalba (Cooke) Hjortstam and Porostereum spadiceum (Pers.) Hjortstam \& Ryvarden were chosen as outgroups.

Alignment of sequences was done by Clustal X. The evolutionary history was inferred by using the Maximum Likelihood method with default settings based on the Tamura-Nei model (Tamura \& Nei 1993) with 1000 bootstraps replications. Initial tree(s) for the heuristic search were obtained automatically by applying Neighbor-Join and BioNJ algorithms to a matrix of pairwise distances estimated using the Maximum Composite Likelihood (MCL) approach, and then selecting the topology with superior log likelihood value. Phylogenetic analysis was done in MEGA 7.0 (Kumar et al. 2016).

Table 1 Species, and sequences used in molecular analysis (arranged alphabetically).

\begin{tabular}{cccc}
\hline \multicolumn{2}{c}{ GenBank (ITS) } & Location & References \\
\hline Phanerochaete brunnea & KX212220 & China & Liu \& He 2016 \\
Phanerochaete ericina & KP135165 & USA & Floudas \& Hibbett \\
& & & 2015 \\
Phanerochaete ericina & KP135167 & USA & Floudas \& Hibbett \\
& & & 2015 \\
Phanerochaete laevis & KP135149 & USA & Floudas \& Hibbett \\
$\begin{array}{c}\text { Phanerochaete porostereoides } \\
\text { Phanerochaete porostereoides }\end{array}$ & KX212217 & China & 2015 \\
Khanerochaete stereoides & KX212218 & China & Liu \& He 2016 \\
Phanerochaete thailandica & MF467737 & China & Liu \& He 2016 \\
Phlebiopsis flavidoalba & KP135402 & USA & Liu \& He 2016 \\
Porostereum spadiceum & KJ668473 & Korea & Floudas \& Hibbett \\
& & & Jang et al. 2016 \\
\hline
\end{tabular}

\section{Results}


Phanerochaete thailandica Kout \& Sádlíková, sp. nov.

Figs $1-5$

MycoBank 821779

Etymology - referring to the locality of the species in Thailand.

Type -Thailand, Krabi Province, south of Koh Lanta Yai island, near Mu Koh Lanta National Park, Bamboo Bay resort, on the dead angiosperm trunk, 1 July 2015, M. Sádlíková (holotype in PRM 945578, isotype in CBG).

Fruiting body annual, easily separable, resupinate, soft, 250-270 $\mu \mathrm{m}$ thick in section, with remarkable brown subiculum. Hymenial surface smooth, not cracked when dry, beige, buff, creamy; margin sometimes fimbriate, whitish, colour unchanged with $\mathrm{KOH}$ solution (except darkening).

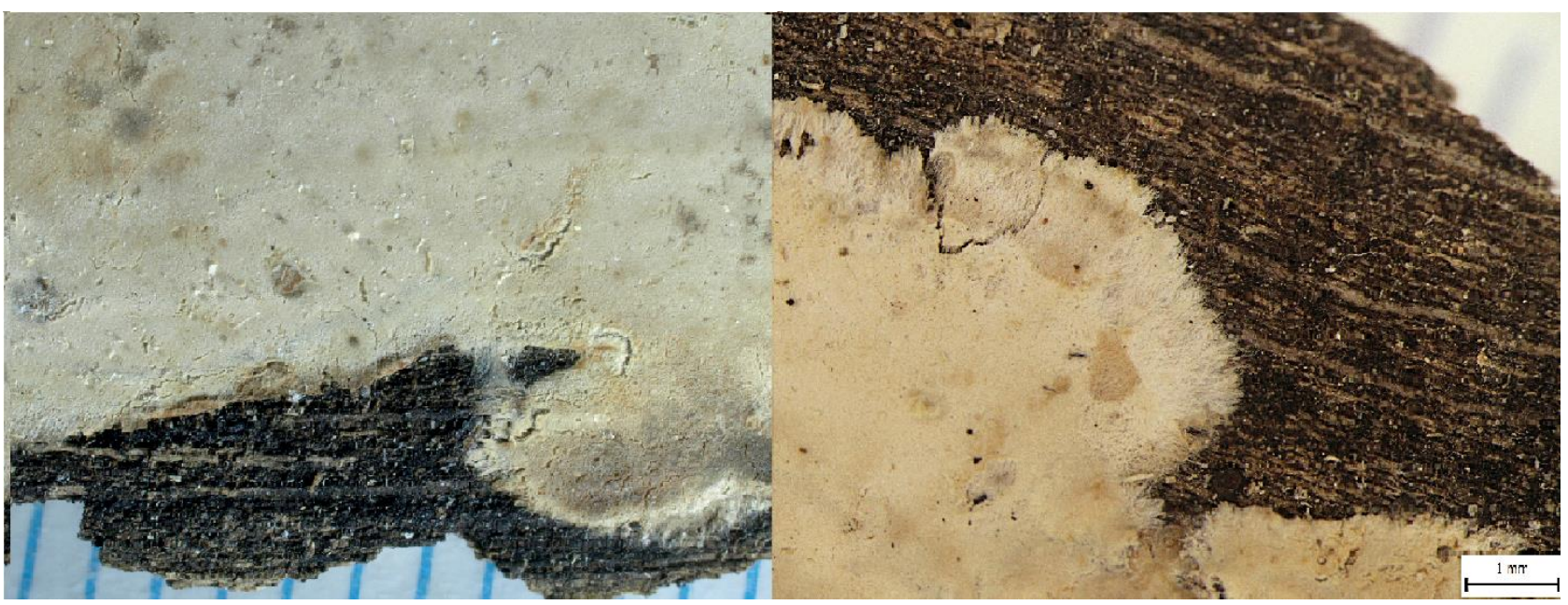

Figure 1 - Phanerochaete thailandica. Fruiting body. - Bars $=1 \mathrm{~mm}$.

Hyphal system monomitic with predominant unclamped, thin-walled hyphae; in subhymenium often finely incrusted by granular crystals, with right-angled anastomoses between hyphae, relatively short celled, hyaline, 2-4 $\mu \mathrm{m}$ in diam; subiculum approx. $150 \mu \mathrm{m}$ thick, hyphae horizontal, loosely interwoven, branching, often septate, occasionally with single clamp or multiple clamps, mainly thinwalled, sometimes slightly thick-walled, partially incrusted, brown, 3-6 $\mu \mathrm{m}$ in diam., quasi-binding hyphae often.

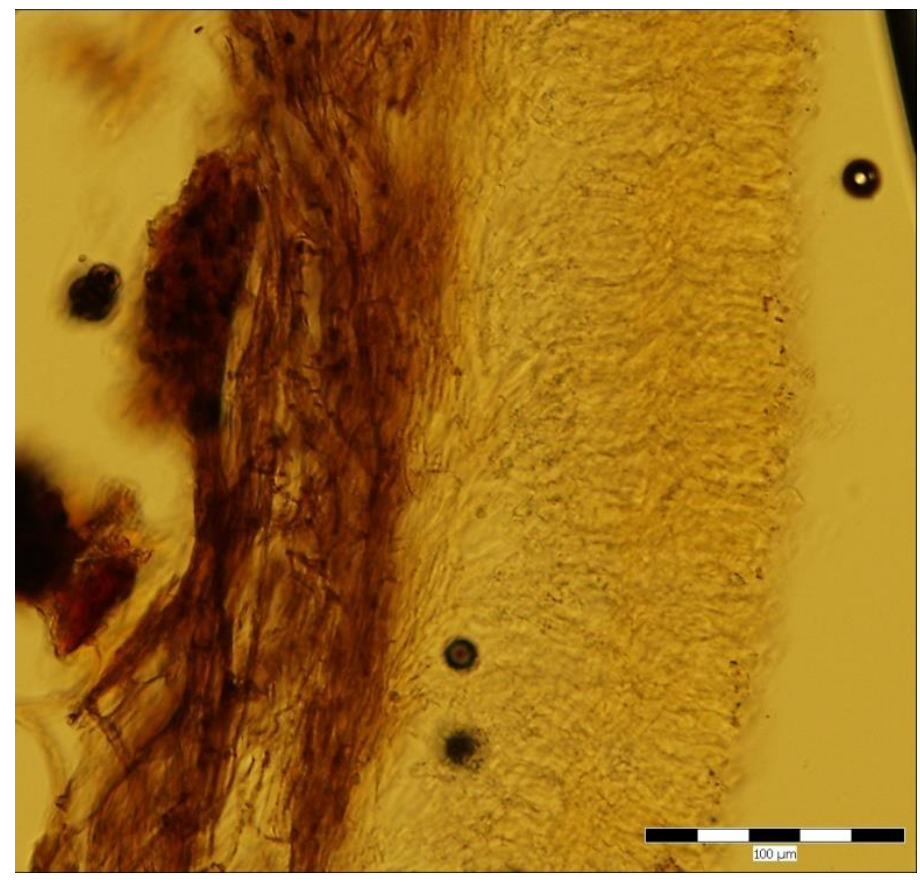


Figure 2 - Phanerochaete thailandica. Vertical section of fruiting body with remarkable brown subiculum. - Bar $=100 \mu \mathrm{m}$.

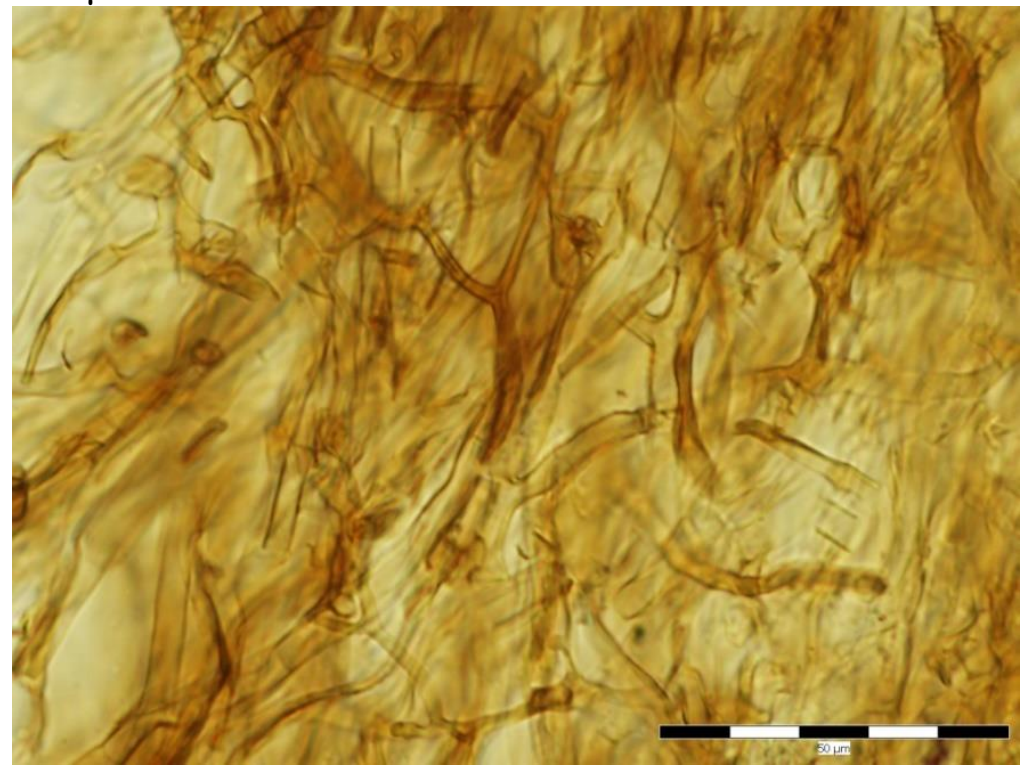

Figure 3 - Phanerochaete thailandica. Detail view in subiculum with quasi-binding hyphae. - Bar $=50 \mu \mathrm{m}$.

Leptocystidia occasionally present, slightly projecting outside of hymenium, thin-walled, cylindrical, obtuse, sometimes up to subcapitate, attenuated to the base, hyaline, 33-62 $\times 5-7 \mu \mathrm{m}$. Basidia with four sterigmata, without basal clamp, narrowly clavate, 25-38 $\times 5-7 \mu \mathrm{m}$. Basidiospores ellipsoid, thin-walled, smooth, hyaline, sometimes with one guttule, 7-8(-8.5) $\times(3.5-) 4-4.5(-5) \mu \mathrm{m}$, $\mathrm{L}=7.39, \mathrm{~W}=4.11, \mathrm{Q}=1.79(\mathrm{n}=20)$. All structures without reaction in Melzer`s solution.

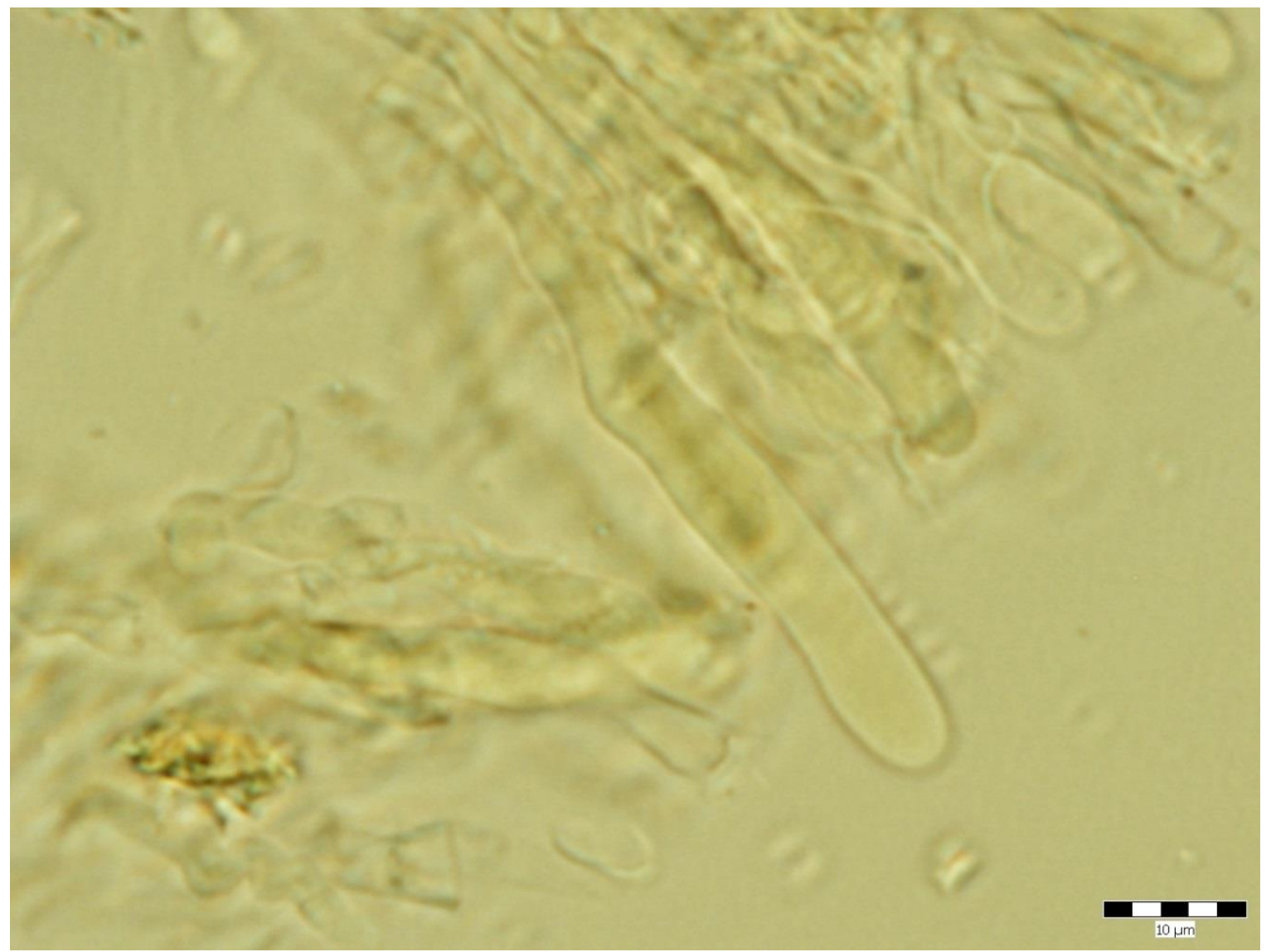


Figure 4 - Phanerochaete thailandica. Leptocystidium. - Bar $=10 \mu \mathrm{m}$.

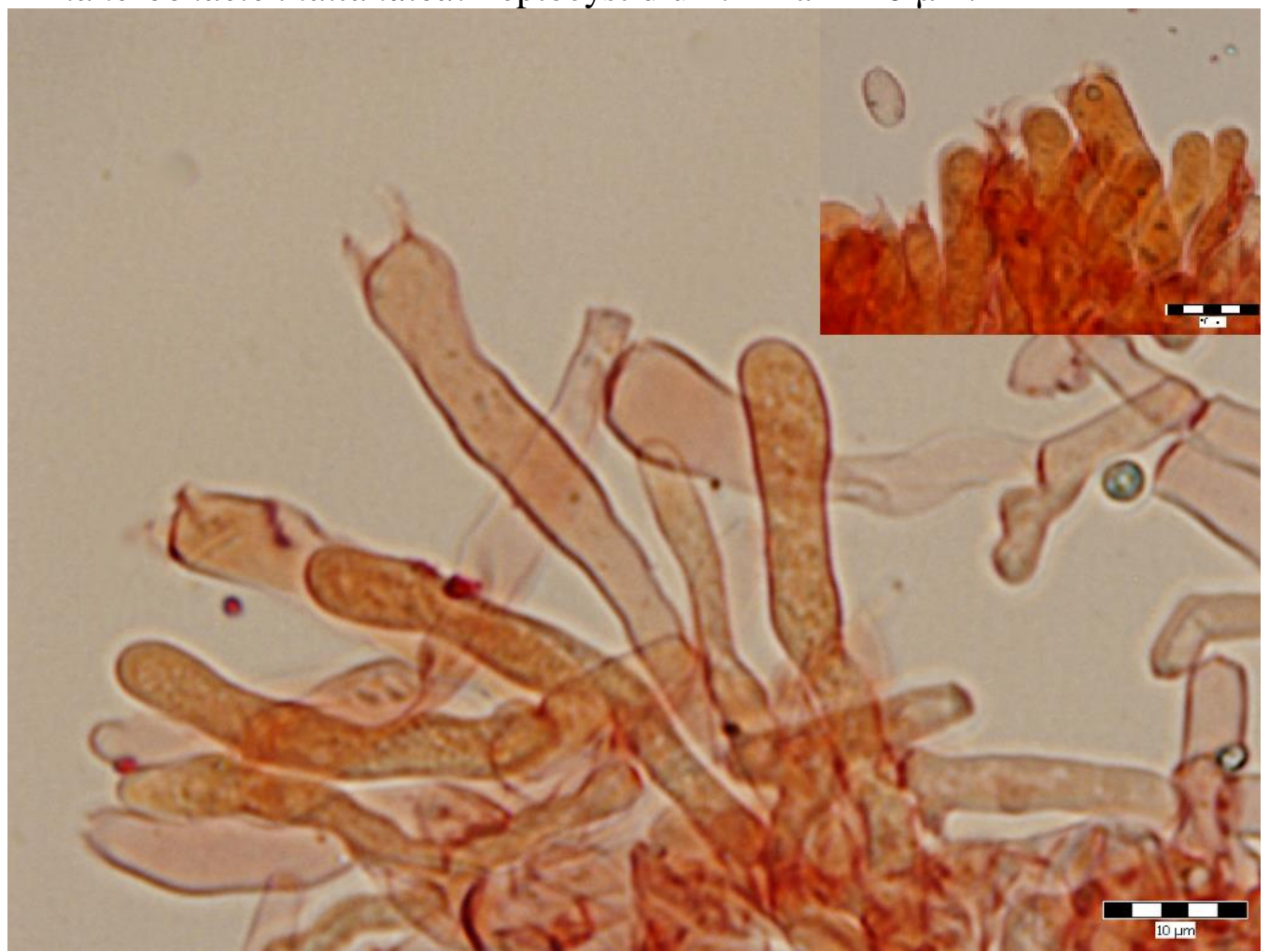

Figure 5 - Phanerochaete thailandica. Part of hymenium with basidia. - Bars $=10 \mu \mathrm{m}$.

Type of rot - White rot.

Known distribution - Known from type locality only but probably more spreading at least in tropical region in Asia.

\section{Discussion}

Phanerochaete thailandica is described based on morphological and molecular evidence, and is characterized by brown subicular hyphae with clamps, quasi-binding hyphae and rather big ellipsoid basidiospores. In addition, it formed a lineage in the Phanerochaete clade (Fig. 6).

The term of quasi-binding hyphae was introduced by $\mathrm{Wu}(\mathrm{Wu} 1990)$ for distinguishing from true binding hyphae. It is expected that, as a morphological feature, quasi-binding hyphae are not specific only for corticioid species; e.g. Chen and Cui (2013) reported it by polypore. Phanerochate ericina (Bourdot) J. Erikss. \& Ryvarden and Phanerochaete subceracea (Burt) Burds. have densely branched subicular hyphae, but they are hyaline, and their basidospores are smaller than that of $P$. thailandica (Burdsall 1985, Wu 1990).

Phanerochaete brunnea Sheng $\mathrm{H}$. Wu, known from China, is similar to P. thailandica by external habitat and brown subicular hyphae (Liu \& He 2016) but it has smaller basidiospores (4.5$5.5 \times 2.3-3 \mu \mathrm{m}, \mathrm{Wu} 1990$ ) and lacks quasi-binding hyphae. Similarly Phanerochaete singularis (G. Cunn.) Burds., from New Zealand and South America (Burdsall 1985, Martínez \& Nakasone 2005) with spores 5.5-7.5 × 2.5-3.5 $\mu \mathrm{m}$ (Burdsall 1985).

Phanerochaete stereoides Sheng H. Wu is closely related to P. thailandica (Fig. 6) but the former has greyish hymenophore. 


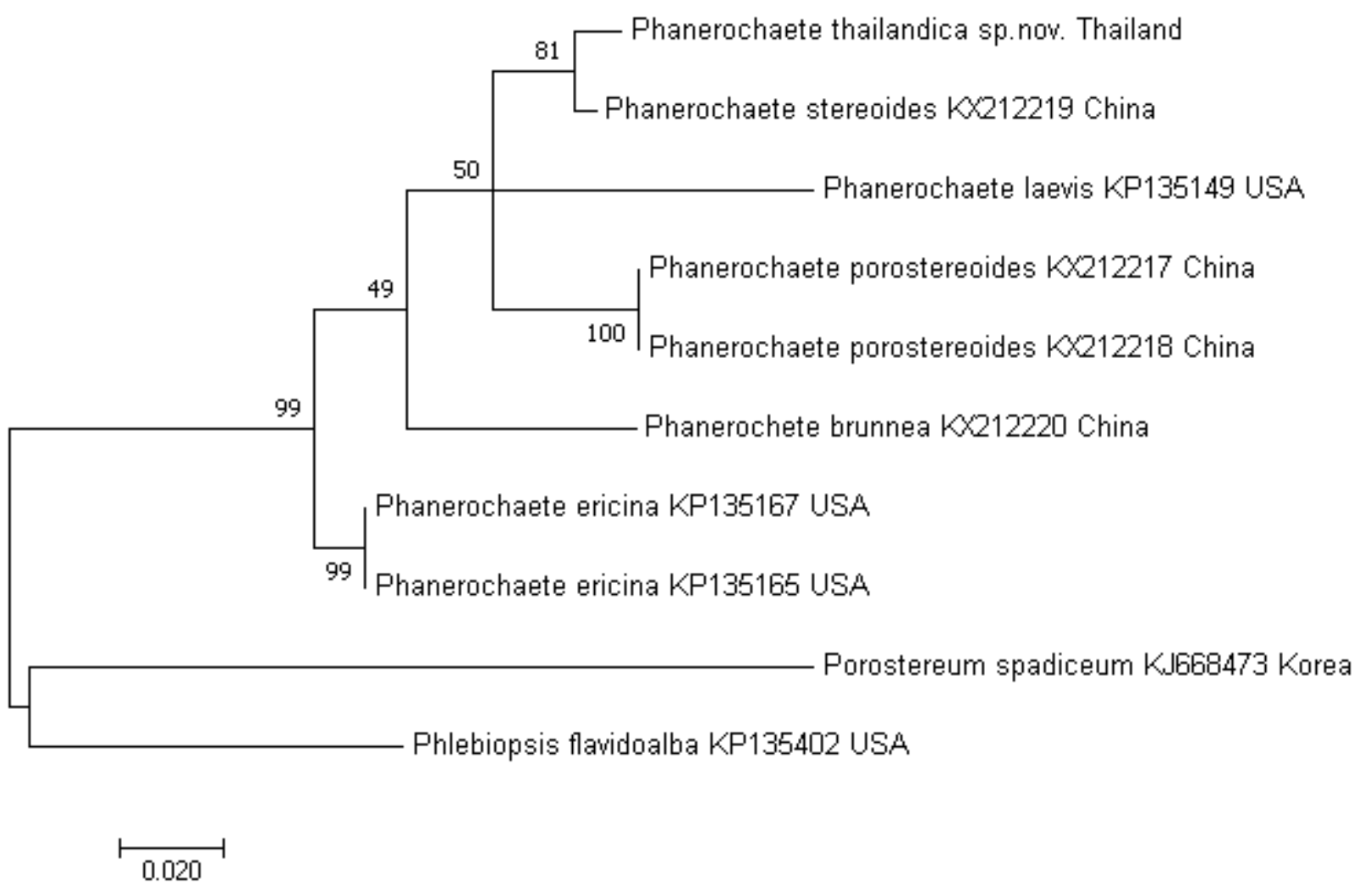

Figure 6 - Maximum-likelihood phylogram of evolutionary relationships of Phanerochaete thailandica. The tree with the highest log likelihood (-2269.19) is shown. The percentage of trees in which the associated taxa clustered together is shown next to the branches. The tree is drawn to scale, with branch lengths measured in the number of substitutions per site.

\section{Acknowledgements}

We thank Dr. J. Vlasák (Czech Republic, Biology Centre ASCR) for the isolation of DNA. and Dr. Shuang-Hui He (China, Institute of Microbiology, Beijing Forestry University) for providing sequences.

\section{References}

Bernicchia A, Gorjón SP. 2010 - Corticiaceae s.l. Candusso, Italia.

Burdsall HH Jr. 1985 - A contribution to the taxonomy of the genus Phanerochaete (Corticiaceae, Aphyllophorales). Mycologia Memoirs 10, 1-165.

Chen JJ, Cui BK. 2013 - Phlebiporia bubalina gen. et. sp. nov. (Meruliaceae, Polyporales) from Southwest China with a preliminary phylogeny based on rDNA sequences. Mycological Progress 13, 563-573.

Dai YC. 2011 - A revised checklist of corticioid and hydnoid fungi in China for 2010. Mycoscience $52,69-79$.

de Koker T, Nakasone KK, Haarhof J, Burdsall HH Jr., Janse BJH. 2003 - Phylogenetic relationships of the genus Phanerochaete inferred from the internal transcribed spacer region. Mycological Research 107, 1032-1040.

Eriksson J, Hjortstam K, Ryvarden L. 1978 - The Corticiaceae of North Europe. Mycoaciella Phanerochaete. Fungiflora 5, 889-1047.

Floudas D, Hibbett DS. 2015 - Revisiting the taxonomy of Phanerochaete (Polyporales, Basidiomycota) using a four gene dataset and extensive ITS sampling. Fungal Biology 119, 679-719. 
Hakimi MH, Vaidya JG, Ranadive KR, Jamaluddin, Jite PK. 2013 - Resupinate Aphyllophorales of India. Scientific Publishers, Jodpuhr.

Jang Y, Jang S, Lee J, Lee H, Lim YW, Kim Ch, Kim J-J. 2016 - Diversity of Wood-Inhabiting Polyporoid and Corticioid Fungi in Odaesan National Park, Korea. Mycobiology 44, 217-236.

Karsten PA. 1889 - Kritisk öfversigt af Finlands Basidsvampar (Basidiomycetes; Gastero- \& Hymenomycetes). Bidrag till Kännedom av Finlands Natur och Folk. 48, 1-470.

Kumar S, Stecher G, Tamura K. 2016 - MEGA7: Molecular Evolutionary Genetics Analysis version 7.0 for bigger datasets. Molecular Biology and Evolution 33, 1870-1874.

Liu SL, He SH. 2016 - Phanerochaete porostereoides, a new species in the core clade with brown generative hyphae from China. Mycosphere 7, 648-655.

Martínez S, Nakasone KK. 2005 - The genus Phanerochaete (Corticiaceae, Basidiomycotina) sensu lato in Uruguay. Sydowia 57, 94-101.

Murray MG, Thompson WF. 1980 - Rapid isolation of high molecular weight plant DNA. Nucleic Acids Research 8, 4321-4325.

Parmasto E. 1968 - Conspectus Systematis Corticiacearum. Institutum zoologicum et botanicum Academiae scientiarum R.P.S.S. Estonicae, Tartu.

Sharma JR. 2012 - Aphyllophorales of Himalaya (Auriscalpiaceae/Tremellodendropsis). Botanical Survey of India, Kolkata.

Spirin V, Kout J, Vlasák J. 2015 - Studies in the Truncospora ohiensis - T. ochroleuca group (Polyporales, Basidiomycota). Nova Hedwigia 100, 159-175.

Tamura K, Nei M. 1993 - Estimation of the number of nucleotide substitutions in the control region of mitochondrial DNA in humans and chimpanzees. Molecular Biology and Evolution 10, 512 526.

Thiers B. [continuously updated] - Index Herbariorum: A global directory of public herbaria and associated staff. New York Botanical Garden's Virtual Herbarium. http://sweetgum.nybg.org/science/ih/ (accessed 14 June 2017).

White TJ, Bruns T, Lee S, Taylor J. 1990 - Amplification and direct sequencing of fungal ribosomal RNA genes for phylogenetics. In: Innis MA, Gelfand DH, Sninsky JJ, White TJ (eds.), PCR Protocols: a guide to methods and applications, Academic Press, San Diego, pp 315-322.

Wu SH. 1990 - The Corticiaceae (Basidiomycetes) subfamilies Phlebioideae, Phanerochaetoideae and Hyphodermoideae in Taiwan. Acta Botanica Fennica 142, 1-123.

Wu SH. 1995 - A study of the genus Phanerochaete (Aphyllophorales) with brown subicular hyphae. Mycotaxon 54, 163-172.

Wu SH. 1998 - Nine new species of Phanerochaete from Taiwan. Mycological Research 102, 11261132.

Wu SH, Nilsson HR, Chen CT, Yu SY, Hallenberg N. 2010 - The white-rotting genus Phanerochaete is polyphyletic and distributed throughout the phlebioid clade of the Polyporales (Basidiomycota). Fungal Diversity 42, 107-118. 